\title{
МЕДНЫЙ ЧЕКАН КУНЧЕ ХАНА В УЗКЕНДЕ
}

\author{
() 2020 г. А. О. Брагин, Б. И. Леонов
}

В настоящее время основной целью джучидской нумизматики Присырдарьинского региона последнего тридцатилетия XIV в., и данной статьи в частности, является кропотливый поиск неизвестных ранее местных монетных выпусков и ввод их в научный оборот. Впервые описан медный джучидский пул, битый в 783/1381-1382 гг. на монетном дворе Узкенд (Присырдарьинский регион) от имени хана Кунче. О серебряном чекане этого эмитента уже сообщалось в научных изданиях ранее. События конца XIV века в районе рек Арысь и Сырдарья в значительной степени остаются белым пятном в истории Золотой Орды и государства Тимура Тамерлана. Время правления Кунче в качестве хана в присырдарьинских землях можно ограничить рамками 782-784/1380-1383 гг.

Ключевые слова: археология, Джучиды, Золотая Орда, Тукатимуриды, Тимуриды, Токтамыш, Кунче-хан, монеты, пул, денежная политика, река Арысь, река Сырдарья, Узкенд

\section{Введение}

В Туркестанской области в районе впадения реки Арысь в Сырдарью (точное место находки установить не удалось) в 2018 г. на поверхности земли на распашке местным жителем была найдена необычная медная монета, изображение которой было любезно предоставлено авторам статьи для изучения. Беглый осмотр изучаемого экземпляра позволил отнести ее к Узкендскому (Присырдарьинский Узкенд) чекану Кунче-хана. На медном пуле в монетной легенде были видны: имя эмитента, название монетного двора и остатки года выпуска.

Целью настоящей публикации является фиксация факта чеканки именных медных монет Тукатимурида Кунче-хана на Узкендском монетном дворе в 783/1381-1382 гг., а также введение в научный оборот уникального нумизматического памятника, раскрывающего особенности монетного дела и денежного обращения в

период правления джучидского хана Кунче.

\section{Описание материала}

Приведем описание данного экземпляра (рис. 1):

№ 1. АЕ пул. Кунче-хан, Узкенд, [78]3 г.х. В=1,55 г; Д=15,3×17 мм.

Л.с. В поле (вид картуша не сохранился) - легенда:

\section{$[\Delta] /$ a[BRA / Ba ..VVÃ $[\Sigma] / \Delta \mathrm{B}$ - on a}

О.с. В поле, заключенном в квадратный картуш:

\section{[78]3 / [f f]ókÀA [L ]j y}

\section{Обсуждение}

Поиск аналогов медных монет в нумизматической литературе, публикациях и доступных музейных собраниях России и Казахстана не дал положительных результатов. Важно отметить, что описываемая монета (рис. 1) является уникальной на дан- 


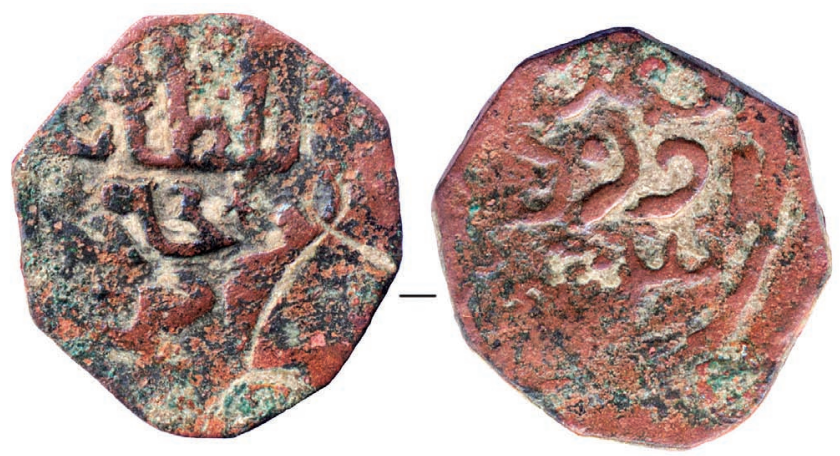

Рис. 1. АЕ пул. Кунче-хан, Узкенд, [78]3 г.х. $B=1,55$ г; Д=15,3×17 мм

Fig. 1. AE pul. Kunche khan. Uzkend mint. [78]3 AH. W=1,55 g; $D=15,3 \times 17 \mathrm{~mm}$

ный момент времени. Но если обратиться к недавним работам Р. Ю. Ревы и А. О. Брагина, в которых изучались Узкендские серебряные данги этого хана, то можно заметить внешнее сходство в оформлении [Рева, Брагин, 2016; 2017]. Для примера приведем изображение серебряного данга (рис. 2) Кунче-хана из присырдарьинского клада конца XIV в. [Рева, Брагин, 2016, с. 285 - № 28].

Опираясь на существующие публикации, мы располагаем фак- тической информацией чекана серебряных монет от имени вновь открытого хана Кунче на таких монетных дворах, как Сыгнак, Узкенд и Сарай (Присырдарьинский). До публикации этих трудов, также выходили единичные статьи, описывающие данги нового монетного двора Узкенд с ошибочным отнесением этих эмиссий к хану Токтамышу [Петров и др., 2014, c. 173; Гончаров, Ержанов, 2015, c. 80-83]. Стиль надписей, состав монетной легенды обеих сторон, как и
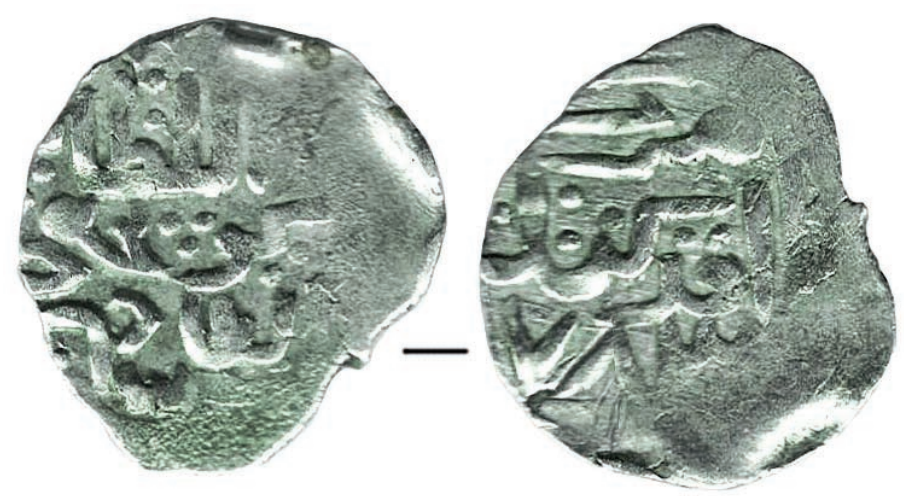

Puc. 2. АR данг. Кунче-хан, Узкенд, 783 г.х. $B=0,99$ г

Fig. 2. AR dang. Kunche khan. Uzkend mint. 783 AH. W=0,99 g 
общее композиционное построение, позволяет сделать выводы о работе одного мастера над штемпелями для медных и серебряных монет на монетном дворе Узкенде.

Хан, чье имя указано на данной монете, не упомянут ни в одном из письменных источников как не марионеточный хан-правитель. Исторические исследования, посвященные истории Джучидов, также обошли этот персонаж своим вниманием и встретить имя Кунче в них невозможно. Это имя упоминается только в статусе царевича - оглана, помощника и близкого сподвижника амира Тимура в 793/1391 г. во время похода сахибкирана на Токтамыша, а после этого уже в статусе оглана как командующего правым флангом войск Токтамыша в 797/1394-1395 г. во время эпического сражения на Тереке. Судя по обнаружению все новых документальных свидетельств, каковыми являются свидетельства нумизматического источника, известные ныне нарративные письменные источники не обеспечивают нас всей необходимой полнотой информации о протекавших исторических событиях в этом регионе.

Кунче оглан (Кундже - ..V命 [Му'изз ..., 2006, с. LVI]) из Тукатимуридской ветви являлся сыном хана Кутлук-Тимура, внуком Нумакана (Нугмана), был братом хана Тимура, отца Тимур-Кутлуга, а также братом Кутлубека - отца Шадибека. У Ибн Халдуна указывается, что отец Кунче - Кутлук-Тимур был провозглашен ханом во время правления Абдаллаха - ставленника Мамая [Шараф ад-Дин, 2008 , с. 390$]$. Брат Кунче - Тимур также был правившим ханом, об этом указано в генеалогических таблицах [Му'изз .., 2006, с. LVI], также он назван Темур-Мелик-ханом - отцом Тимур-Кутлуг-оглана в «Зафар-Наме» [Шараф ад-Дин, 2008, с. 140].
После смерти брата - хана Тимура, Тукатимурид Кунче возглавил род потомков Нумакана. После ухода в 781/1379-1380 г. Токтамыш-хана на завоевание Поволжского престола Кунче оглан, несомненно, считавший себя более достойной кандидатурой на владение троном, объявил себя ханом в землях Сыгнакских. В $782 ?-783 / 1380 ?-1382$ гг. правил в Присырдарьинском Узкенде. Присырдарьинский Узкенд, Кыр-Узгенд, следует отличать от Узгенда Ферганского [Гончаров, Ержанов, 2015, с. 80-83]. В 783/1381-1382 г. Кунче завладел Сыгнаком, где продержался до 784/1382-1383 г. Время правления Кунче в качестве хана в присырдарьинских землях можно ограничить рамками 782-784/1380-1383 гг. Более подробные сведения о личности Кунче-хана и нумизматические свидетельства его правления опубликованы ранее [Рева, Брагин, 2016; 2016а; 2016б; 2017; 2017a]. Право сикка новый правитель реализовал в полном объеме, о чем красноречиво говорят серебряные и медные монеты с его именем. Весть о восшествии на трон Кунче-хана разнеслась по ближайшим областям и дошла до нашего времени также благодаря самим монетам.

\section{Bblвodbl}

Итак, в научный оборот введена информация о чекане именных медных пулов Тукатимурида Кунчехана на монетном дворе Узкенд в 783/1381-1382 г. Сравнительный анализ медного пула с экземплярами серебряных дангов позволяет говорить о работе одного мастера-резчика штемпелей в Узкенде. Важно отметить, что вопрос отсутствия информации в исторических хрониках того времени о фактах появления нового хана и захвата им ключевых городов остается открытым на сегодняшний день. Находка новых кладов, а также 
единичных экземпляров монет, чеканенных на присырдарьинских монетных дворах в конце XIV в., позволит существенно обогатить информацию о монетном деле в правление Кунчехана и, возможно, в дальнейшем под- твердить, дополнить и уточнить сделанные выводы. Сбор таких сведений продолжается авторами методично в целях проведения более детальной реконструкции монетного дела Приаралья конца XIV - начала XVI в.

\section{ЛИТЕРАТУРА}

1. Гончаров Е.Ю., Ержанов А. Город Узгенд: монетный двор и денежное обращение. Южный Казахстан, XIII-XV вв. // Восемнадцатая Всероссийская нумизматическая конференция: тез. докл. и сообщ. (г. Москва, Коломна, 20-25 апреля 2015 г.). М.: Триумф принт, 2015. С. 80-83.

2. Му“изз ал-ансаб. (Прославляющее генеалогии) // История Казахстана в персидских источниках. Алматы: «Дайк-Пресс», 2006. Т. 3. 672 с.

3. Настич B.Н. Улджайтимур-хан: время и деньги (нумизматический обзор) // ЭВ. 2009. Вып. XXVIII. C. 168-186.

4. Петров П.Н., Байпаков К.М., Воякин Д.А. Монетное дело и денежное обращение в Великой Монгольской империи, государствах Чагатаидов и Джучидов на территории Казахстана. Алматы: Институт археологии им. А.Х. Маргулана, 2014. $264 \mathrm{c}$.

5. Рева Р.Ю., Брагин А.О. Присырдарьинский клад конца XIV века (Ч. 1) // Stratum Plus. 2016. № 6. C. 279-293.

6. Рева Р.Ю., Брагин А.О. Нумизматические свидетельства правления Кунчехана // Нумизматика Золотой Орды. 2016а. № 6. С. 87-94, 157

7. Рева Р.Ю., Брагин А.О. История Приаралья в конце XIV века по летописным и нумизматическим данным (Ч. 1. События 773-781 годов Хиджры) // Вестник НГУ. Сер.: История, филология. 2016б. Т. 15, № 7: Археология и этнография. С. 140-148.

8. Рева Р.Ю., Брагин А.О. Присырдарьинский клад конца XIV века (Ч. 2) // Stratum Plus. 2017. № 6. C. 171-189.

9. Рева Р.Ю., Брагин А.О. История Приаралья в конце XIV века по летописным и нумизматическим данным. (Ч. 2. События 781-793 годов Хиджры) // Вестник НГУ. Сер.: История, филология. 2017а. Т. 16. № 3: Археология и этнография. С. 89-97.

10. Тизенгаузен В.Г. Сборник материалов, относящихся к истории Золотой Орды. Т. І. Извлечения из сочинений арабских. СПб.: Издано на иждивение графа С.Г. Строганова, 1884. 566 с.

11. Шараф ад-Дин Али Йазди. Зафар-Наме. Книга побед амира Темура. Ташкент: SANAT, 2008. $488 \mathrm{c}$.

\section{Сведения об авторах:}

Брагин Андрей Олегович - научный сотрудник, Институт археологии им. А.Х. Маргулана (г. Алматы, Казахстан), аспирант, Центр исследований истории Золотой Орды, Институт истории им. Ш. Марджани (г. Казань, Россия); rasmir@mail.ru

Леонов Борис Иванович - исследователь, нумизмат (г. Санкт-Петербург, Россия); overshtag@bk.ru 


\title{
КҮНШЕ ХАННЫН ӨЗГЕНТТЕГІ МЫС АҚША ШЕКІМЕСІ
}

\author{
А. О. Брагин, Б. И. Леонов
}

Қазіргі кезде XIV ғ. соңғы отыз жылындағы Сырдария өңіріндегі жошылық нумизматиканың, оның ішінде осы мақаланың басты мақсаты бұрын беймәлім болып келген жергілікті ақша шығаруды іздестіру және оларды ғылыми айналымға қосу болып табылады. Алғаш рет Күлше ханның атынан Өзкент (Сырдария өңірі) ақша сарайында 783/1381-1382 жж. соғылған мыс жошылық пұл ғылыми айналымға енгізіледі. Осы ақша шығарушының күміс ақша шекімесі туралы осыған дейінде ғылыми басылымдарда айтылған болатын. Арыс пен Сырдария өзендерінің бойындағы XIV ғ. соңындағы оқиға Алтын Орда мен Темір Темірлан мемлекетінің тарихындағы ақтаңдақтар болып қалып келеді. Күнше ханның сырдариялық өңір жерлеріндегі билік еткен мерзімін 782-784/1380-1383 жылдармен шектеуге болады.

Түйін сөздер: археология, жошылықтар, Алтын Орда, Тоқа Темір ұрпақтары, Темір ұрпақтары, Тоқтамыс, Күнше хан, ақшалар, пұл, ақша саясаты, Арыс өзені, Сырдария өзені, Өзкент

\section{COPPER MINTAGE KUNCHE KHAN IN UZKEND}

\section{A. O. Bragin, B. I. Leonov}

The main purpose of the Jochi numismatics of the Syrdarya region of the last thirty years of the XIV century, and of this article in particular, is a detailed search for previously unknown local coin issues and their introduction into scientific circulation. The copper Jochi pūl minted in 783/1381-1382 at the mint with the name of khan Kunche was introduced into scientific circulation for the first time. The silver mint of this issuer has already been reported in scientific publications earlier. The events of the late XIV century in the area of the Arys and Syrdarya rivers largely remain a white spot in the history of the Golden Horde and the state of Timur Tamerlan. The time of Kunche's reign as a khan in the Syrdarya lands can be limited to 782-784/1380-1383.

Keywords: archaeology, Jochids, Golden Horde, Tukatimurids, Timurids, Toktamysh, Kunche khan, coins, pūl, monetary policy, Arys River, Syrdarya River, Uzkend

\section{REFERENCES}

1. Goncharov, E. Yu., Erzhanov, A. 2015. In Vosemnadcataya Vserossijskaya numizmaticheskaya konferenciya (18 ${ }^{\text {th }}$ Russian Numismatic Conference). Moscow: «Triumf print» Publ., 80-83 (in Russian).

2. Mu'izz al-ansab. 2006. Istoriya Kazahstana v persidskih istochnikah (History of Kazakhstan in Persian sources). Almaty: «Dayk-Press» Publ. (in Russian).

3. Nastich, V. N. 2009. In Epigrafika Vostoka (Epigraphy of the East), XXVIII, 168186 (in Russian).

4. Petrov, P. N., Baipakov, K. M., Voyakin, D. A. 2014. Monetnoe delo i denezhnoe obrashchenie $v$ Velikoy Mongolskoy imperii, gosudarstvah Chagataidov i Juchidov. Kazakhstan (Monetary affairs and monetary circulation in the Great Mongol Empire, the states of the Chagataids and the Juchids. Kazakhstan). Almaty: A.Kh. Margulan Institute of Archeology Publ. (in Russian).

5. Reva, R. Yu., Bragin, A. O. 2016. In Stratum Plus, 6, 279-293 (in Russian).

6. Reva, R. Yu., Bragin, A. O. 2016a. In Golden Horde Numismatics, 6, 87-94, 157 (in Russian). 
7. Reva, R. Yu., Bragin, A. O. 2016b. In Bulletin of Novosibirsk State University, 15, no. 7, 140-148 (in Russian).

8. Reva, R. Yu., Bragin, A. O. 2017. In Stratum Plus, 6, 171-189 (in Russian).

9. Reva, R. Yu., Bragin, A. O. 2017a. In Bulletin of Novosibirsk State University, 16, no. 3, 89-97 (in Russian).

10. Tizengauzen, V. G. 1884. Sbornik materialov, otnosyashchihsya k istorii Zolotoy Ordy (The collection of materials related to the history of the Golden Horde). Saint Petersburg: "Izdano na izhdivenie grafa S.G. Stroganova" Publ. (in Russian).

11. Sharaf ad-Din Ali Jazdi. 2008. Zafar-Name. Kniga pobed amira Temura (Amir Timur's book of victories). Tashkent: SANAT Publ. (in Russian).

\section{About the Authors:}

Bragin Andrey O. Researcher, A.Kh. Margulan Archeology Institute, Almaty, Kazakhstan; Post-graduate student, Center for Research of History of the Golden Horde, Sh. Marjani Institute of History, Academy of Sciences of the Republic of Tatarstan, Kazan, Russia; rasmir@mail.ru

Leonov Boris I. Researcher, Numismatist, Saint Petersburg, Russia; overshtag@bk.ru

\footnotetext{
Мүдделер қақтығысы туралы ақпаратты ашу. Авторлар мүдделер қақтығысының жоқтығын мәлімдейді. / Раскрытие информации о конфликте интересов. Авторы заявляют об отсутствии конфликта интересов. / Disclosure of conflict of interest information. The authors claims no conflict of interest.

Мақала туралы ақпарат / Информация о статье / Information about the article. Редакцияға түсті / Поступила в редакцию / Entered the editorial office: 04.11.2019.

Рецензенттер мақұлдаған / Одобрено рецензентами / Approved by reviewers: 11.11.2019. Жариялауға қабылданды / Принята к публикации / Accepted for publication: 18.11.2019.
} 